\title{
IMPLEMENTASI PENILAIAN KINERJA GURU DALAM KEGIATAN SUPERVISI PEMBELAJARAN DI SDN 04 DUHIADAA
}

\author{
Yurni Abdullah ${ }^{1}$, Rahmawati $^{2}$, Damhuri $^{3}$ \\ ${ }^{123}$ Pascasarjana IAIN Sultan Amai Gorontalo \\ Email:yurni@gmail.com
}

\begin{abstract}
ABSTRAK
Artikel ini bertujuan untuk menggali bagaimana implementasi penilaian kinerja guru dalam kegiatan supervisi pembelajaran di SDN 04 Duhiadaa. Metode yang digunakan dalam penelitian ini masuk dalam jenis penelitian kualitatif dengan teknik pengumpulan data melalui teknik observasi, wawancara, dan dokumentasi. Hasil penelitian menemukan bahwa Implementasi penilaian kinerja guru dalam supervisi pembelajaran seperti pelaksanaan proses pembelajaran bagi guru mata pelajaran atau guru kelas, yang meliputi kegiatan merencanakan dan melaksanakan pembelajaran, mengevaluasi dan menilai. Selain itu, dalam proses evaluasi kinerja guru difokuskan pada aspek yang berhubungan dengan kompetensi pedagogik, kompetensi profesional guru, kompetensi kepribadian dan kompetensi sosial guru.
\end{abstract}

Kata Kunci: Penilaian Kinerja Guru, Supervisi Pembelajaran

\begin{abstract}
This article aims to explore how the implementation of teacher performance evaluation in learning supervision activities at SDN 04 Duhiadaa. The research method used is included in the type of qualitative research with data collection techniques through observation, interviews, and documentation. The results found that the implementation of teacher performance appraisals in the supervision of learning such as the implementation of the learning process for subject teachers or class teachers, which includes activities to plan and carry out learning, evaluating and assessing. In addition, the teacher performance evaluation process focuses on aspects related to pedagogical competence, professional competence of teachers, personality competencies and social competencies of teachers.
\end{abstract}

Keywords: Teacher Performance Appraisal, Learning Supervision

\section{PENDAHULUAN}

Dalam rangka melaksanakan peran dan upaya peningkatan mutu pendidikan dewasa ini, maka perlu kerjasama yang baik antara kepala sekolah dengan guru, dan bertanggung jawab penuh terhadap keberhasilan peserta didik. Kepala sekolah secara mandiri harus memiliki tanggung jawab terhadap pengembangan sumber daya yang ada di sekolah, sehingga kebutuhan belajar siswa dapat dipenuhi. Kepala sekolah dituntut senantiasa berusaha membina dan 
mengembangkan hubungan kerjasama yang baik guna mewujudkan kinerja guru yang efektif dan efisien.

Undang-Undang Nomor 20 Tahun 2003 Tentang Sistem Pendidikan Nasional menjelaskan bahwa kepala madrasah mendapat tugas sebagai supervisor yang diharapkan dapat setiap kali berkunjung ke kelas dan mengamati kegiatan guru yang sedang mengajar. Mengingat di bidang pendidikan dan pembelajaran diperlukan penyelia (supervisor) yang dapat berdialog serta membantu pertumbuhan pribadi guru sesuai dengan profesinya. ${ }^{1}$ Mengacu kepada Permennegpan dan RB No. 16 Tahun 2009, terdapat 4 (empat) kelompok guru yang wajib dinilai kinerjanya yakni guru mata pelajaran/guru kelas, guru bimbingan konseling/konselor, guru dengan tugas tambahan yang relevan dengan fungsi sekolah/madrasah, dan penilaian terhadap guru PNS yang diperbantukan di sekolah swasta. $^{2}$

Penilaian kinerja guru mata pelajaran dilakukan dengan mengacu kepada dimensi tugas utama guru yang meliputi kegiatan merencanakan dan melaksanakan pembelajaran, mengevaluasi dan menilai termasuk di dalamnya menganalisis hasil penilaian dan melaksanakan tindak lanjut hasil penilaian. Dimensi tugas utama ini kemudian diturunkan menjadi indikator kinerja yang terukur sebagai bentuk unjuk kerja guru dalam melaksanakan tugas utamanya tersebut akibat dari kompetensi yang dimiliki guru.

Berdasarkan Peraturan Pemerintah Nomor 55 Tahun 2007 tentang Pendidikan Agama yang dilaksanakan oleh Menteri Agama dan Permendikbud Nomor 160 Tahun 2014 bahwa Kurikulum 2013 tidak diberhentikan secara substansial menyatakan bahwa: “(1) Mata Pelajaran Pendidikan Agama Islam dan Budi Pekerti tetap mengimplementasikan Kurikulum 2013 di semua sekolah; (2) Proses pembelajaran menggunakan pendekatan saintifik dengan alokasi waktu sesuai dengan kurikulum 2013 dan proses penilaian disesuaikan dengan kebijakan satuan pendidikan masing-masing; ${ }^{3}$

Kepala sekolah dalam melakukan supervisi terkait dengan kinerja guru, kompetensi yang dijadikan dasar penilaian kinerja guru adalah kompetensi pedagogik, profesional, sosial dan kepribadian, sebagaimana ditetapkan dalam Peraturan Menteri Pendidikan Nasional Nomor 16 Tahun 2007. Keempat kompetensi ini telah dijabarkan menjadi subkompetensi dan indikator yang harus dapat ditunjukkan dan diamati dalam berbagai kegiatan, tindakan, dan sikap guru agar sesuai dengan pembelajaran yang diterapkan dalam Kurikulum 2013.

\footnotetext{
${ }^{1}$ Departemen Pendidikan Nasional RI, Undang-undang Republik Indonesia Nomor 20 Tahun 2003 Tentang Sistem Pendidikan Nasional, (Bandung: Citra Umbara; 2003), h. 23.

2Permennegpan dan RB No. 16 Tahun 2009 Tentang Jabatan Fungsional Guru dan Angka Kreditnya

${ }^{3}$ Peraturan Pemerintah Nomor 55 Tahun 2007 tentang Pendidikan Agama yang dilaksanakan oleh Menteri Agama dan Permendikbud Nomor 160 Tahun 2014.
} 
Pengamatan penulis terkait implementasi penilaian kinerja guru yang dilakukan oleh kepala sekolah tampaknya masih cukup tertutup padahal banyak kelemahan guru yang ditemukannya dalam pembelajaran pendidikan agama Islam dengan menerapkan kurikulum 2013. Hal ini dibuktikan oleh kenyataan yang penulis temukan di lapangan terkait dengan kepala sekolah ternyata tidak mudah untuk mendapatkan data dan mengamati realitas keseharian performance guru di hadapan peserta didiknya. Memang program kunjungan kelas oleh kepala sekolah, tidak mungkin ditolak oleh guru. Akan tetapi tidak jarang terjadi guru mata pelajaran berusaha menampakkan kinerja terbaiknya baik pada aspek perencanaan maupun pelaksanaan pembelajaran hanya saat dikunjungi. Selanjutnya guru kembali mengajar seperti sedia kala, kadang tanpa persiapan yang matang serta tanpa semangat dan antusiasme yang tinggi. Sedangkan kepala sekolah selain kurang melibatkan guru dalam kegiatan penyusunan program supervisi juga terkadang kepala sekolah tidak memberikan tindakan pembinaan serta mengutus guru mengikuti penataran seperti workshop, FGD, seminar dan lain sebagainya yang terkait dengan peningkatan kompetensinya di bidang pendidikan.

\section{PENILAIAN KINERJA GURU MATA PELAJARAN}

Guru mata pelajaran adalah guru yang bertanggung jawab melaksanakan pembelajaran untuk mata pelajaran tertentu pada satuan pendidikan Sekolah Dasar dan yang sederajad, Sekolah Menengah Pertama dan yang sederajat, Sekolah Menengah Atas dan yang sederajat, serta Sekolah Menengah Kejuruan atau Madrasah Aliyah Kejuruan. Tugasnya adalah membantu guru kelas dan guru pembimbing khusus dalam pelaksanaan pembelajaran yang efektif bagi peserta didik. Sedangkan guru kelas adalah guru yang mengikuti kelas pada satuan pendidikan sekolah dasar atau yang sederajat, yang bertugas melaksanakan pembelajaran seluruh mata pelajaran pada satuan pendidikan tersebut, kecuali pendidikan agama dan olahraga.

Penilaian kinerja guru mata pelajaran/guru kelas adalah yang terkait dengan pelaksanaan proses pembelajaran yang meliputi aspek-aspek kegiatan merencanakan dan melaksanakan pembelajaran, menilai, menganalisis hasil penilaian, dan melaksanakan tindak lanjut hasil penilaian dalam menrapkan 4 (empat) kompetensi yang harus dimiliki oleh guru sesuai dengan peraturan Menteri Pendidikan Nasional Nomor 16 Tahun 2007 tentang Standar Kualifikasi Akademik dan Kompetensi Guru. Pengelolaan pembelajaran tersebut mensyaratkan guru untuk menguasai kompetensi pedagogik, kepribadian, sosial, dan profesional, sesuai dengan peran dan fungsinya masing-masing. ${ }^{4}$

${ }^{4}$ Undang-Undang Republik Indonesia No. 16 Tahun 2007 Tentang Standar Kualifikasi Akademik dan Kompetensi Guru. 
Sesuai dengan amanat Peraturan Pemerintah Nomor 32 Tahun 2013 Tentang Standar Nasional Pendidikan salah satu standar yang harus dikembangkan adalah standar proses. Standar proses adalah standar nasional pendidikan yang berkaitan dengan pelaksanaan pembelajaran pada satuan pendidikan untuk mencapai kompetensi lulusan. Standar proses berisi kriteria minimal proses pembelajaran yang ditetapkan pemerintah pada satuan pendidikan dasar dan menengah di seluruh wilayah hukum Negara Kesatuan Republik Indonesia. Standar proses ini berlaku untuk jenjang pendidikan dasar dan menengah pada jalur formal, baik pada sistem paket maupun pada sistem kredit semester. ${ }^{5}$ Pengawasan proses pembelajaran meliputi pemantauan, supervisi, evaluasi, pelaporan, dan pengambilan langkah tindak lanjut yang diperlukan. ${ }^{6}$

Berkaitan dengan kinerja guru dalam melaksanakan kegiatan pembelajaran sesuai dengan standar yang ditetapkan, terdapat Tugas Keprofesionalan Guru yang diatur dalam Undang-undang Republik Indonesia No 14 Tahun 2005 Pasal 20 (a) Tentang Guru dan Dosen yang terdiri atas tiga proses yaitu: merencanakan pembelajaran, melaksanakan proses pembelajaran yang bermutu, serta menilai dan mengevaluasi hasil pembelajaran. ${ }^{7}$

Agar kepala sekolah dapat melaksanakan kegiatan penilaian kinerja guru di tingkat sekolah dengan baik maka perlu memperhatikan mekanismenya yang harus dilaksanakan dalam 4 (empat) tahapan. Ke empat tahapan mekanisme penilaian kinerja guru secara sistematis dapat penulis uraikan di bawah ini:

\section{Tahap persiapan}

Penilai kinerja guru maupun guru yang akan dinilai, harus memahami pedoman penilaian kinerja guru. Pemahaman penilai kinerja guru bukan saja memberikan kemudahan dalam pelaksanaan penilaian kinerja guru namun juga memudahkan kepala sekolah dalam pencapaian tujuan penilaian kinerja guru sesuai dengan pedoman dan peraturan serta perundangan yang berlaku di bidang pendidikan.

Di antara pedoman yang harus dimiliki dan dipahami oleh kepala sekolah sebagai acuan dalam implementasi penilaian kinerja guru adalah: (1) Buku 2 Penilaian Kinerja Guru (PKG) Kementerian Pendidikan Nasional Direktorat Jenderal Peningkatan Mutu Pendidik dan Tenaga Kependidikan 2010, (2) Peraturan Menteri Negara Pendayagunaan Aparatur Negara dan Reformasi Birokrasi Nomor 16 Tahun 2009 tentang Jabatan Fungsional Guru dan Angka Kreditnya, dan (3) Peraturan Bersama Menteri Pendidikan Nasional dan Kepala Badan Kepegawaian Negara Nomor 14 Tahun 2010 dan Nomor 03/V/PB/2010

\footnotetext{
${ }^{5}$ Peraturan Pemerintah RI Nomor 32 Tahun 2013 tentang Standar Nasional Pendidikan

${ }^{6}$ Wina Sanjaya, Implementasi Kurikulum Tingkat Satuan Pendidikan Kemandirian Guru dan Kepala Sekolah (Ed. I; Cet. III; Jakarta: Bumi Aksara, 2009), h. 24-25.

${ }^{7}$ Undang-Undang Republik Indonesia No 14 Tahun 2005 Tentang Guru dan Dosen
} 
tentang Petunjuk Pelaksanaan Jabatan Fungsional Guru dan Angka Kreditnya, serta (4) Peraturan Menteri Pendidikan Nasional Nomor 35 tahun 2010 tentang Petunjuk Teknis Pelaksanaan Jabatan Fungsional Guru dan Angka Kreditnya.

Selain itu upaya pemerintah dalam peningkatan pemahaman kepala sekolah dalam peningkatan kinerja guru melalui penilaian kinerja dikuatkan dengan Peraturan Presiden Republik Indonesia No 2/ 2015 Tentang Rpjmn 20152019 tentang Arah Kebijakan dan Strategi Pembangunan sub bidang pendidikan diprioritaskan untuk: Meningkatkan profesionalisme, kualitas, dan akuntabilitas guru dan tenaga kependidikan melalui: penguatan sistem Uji Kompetensi Guru sebagai bagian dari proses penilaian hasil belajar siswa; pelaksanaan penilaian kinerja guru yang sahih dan andal serta dilakukan secara transparan dan berkesinambungan; peningkatan kualifikasi akademik dan sertifikasi guru dengan perbaikan desain program dan keselarasan disiplin ilmu; pelaksanaan Pengembangan Profesional Berkesinambungan (PPB) bagi guru dalam jabatan melalui latihan berkala dan merata, serta penguatan KKG/MGMP; dan pelaksanaan pembinaan karir, peningkatan kualifikasi, pengembangan profesi/kompetensi bagi tenaga kependidikan termasuk kepala sekolah dan pengawas. $^{8}$

Perangkat yang harus digunakan oleh penilai untuk melaksanakan Penilaian Kinerja Guru agar diperoleh hasil penilaian yang obyektif, akurat, tepat, valid, dan dapat dipertanggungjawabkan adalah: (1) Pedoman penilaian kinerja guru yang mengatur tentang tata cara penilaian dan norma-norma yang harus ditaati oleh penilai, guru yang dinilai, serta unsur lain yang terlibat dalam proses penilaian, (2) Instrumen penilaian kinerja yang relevan dengan tugas pembelajaran terdiri atas (lembar pernyataan kompetensi, indikator, dan cara menilai), format catatan dan evaluasi penilaian kinerja per kompetensi, Format rekap hasil penilaian kinerja guru, dan format penghitungan angka kredit; (3) laporan kendali kinerja guru. ${ }^{9}$

Dalam tahap persiapan, hal-hal yang harus dilakukan oleh penilai maupun guru yang akan dinilai. 1) memahami Pedoman Penilaian Kinerja Guru, terutama tentang sistem yang diterapkan dan posisi Penilaian Kinerja Guru dalam kerangka pembinaan dan pengembangan profesi guru; 2) memahami pernyataan kompetensi guru yang telah dijabarkan dalam bentuk indikator kinerja; 3) memahami penggunaan instrumen Penilaian Kinerja Guru dan tata cara penilaian yang akan dilakukan, termasuk cara mencatat semua hasil pengamatan dan pemantauan, serta mengumpulkan dokumen dan bukti fisik lainnya yang memperkuat hasil

\footnotetext{
${ }^{8}$ Peraturan Presiden Republik Indonesia No 2/ 2015 Tentang Rpjmn 2015-2019 tentang Arah Kebijakan dan Strategi Pembangunan

${ }^{9}$ Buku 2 Penilaian Kinerja Guru (PKG) Kementerian Pendidikan Nasional Direktorat Jenderal Peningkatan Mutu Pendidik dan Tenaga Kependidikan 2010
} 
penilaian; dan 4) memberitahukan rencana pelaksanaan Penilaian Kinerja Guru kepada guru yang akan dinilai sekaligus menentukan rentang waktu jadwal pelaksanaannya. $^{10}$

\section{Tahap pelaksanaan}

Beberapa tahapan Penilaian Kinerja Guru yang harus dilalui oleh penilai sebelum menetapkan nilai untuk setiap kompetensi, adalah sebagai berikut yakni sebelum pengamatan, selama pengamatan, dan setelah pengamatan. Untuk lebih jelasnya penulis uraikan secara singkat dan sistematis tentang tahapan pelaksanaan yang dimaksud sebagai berikut:

Sebelum pengamatan, pertemuan awal antara penilai dengan guru yang dinilai sebelum dilakukan pengamatan dilaksanakan di ruang khusus tanpa ada orang ketiga. Pada pertemuan ini, penilai mengumpulkan dokumen pendukung dan melakukan diskusi tentang berbagai hal yang tidak mungkin dilakukan pada saat pengamatan. Semua hasil diskusi, wajib dicatat dalam format laporan dan evaluasi per kompetensi (Lampiran 1B bagi PK Guru Pembelajaran dan Lampiran 2B bagi PK Guru BK/Konselor) sebagai bukti penilaian kinerja.

Selama pengamatan di kelas dan/atau di luar kelas, penilai wajib mencatat semua kegiatan yang dilakukan oleh guru dalam pelaksanaan proses pembelajaran atau pembimbingan yang dilakukan sebaiknya lebih dari satu kali dengan menggunakan instrumen yang tersedia. Setelah pengamatan, pada pertemuan setelah pengamatan pelaksanaan proses pembelajaran, pembimbingan, atau pelaksanaan tugas tambahan yang relevan dengan fungsi sekolah/madrasah, penilai dapat mengklarifikasi beberapa aspek tertentu yang masih diragukan. ${ }^{11}$

Secara teknis sistem pelaksanaan penilaian kinerja guru diawali dengan kegiatan pelaksanaan evaluasi diri, dilanjutkan dengan pelaksanaan Penilaian Kinerja Guru dalam periode 4 sampai dengan 6 minggu di akhir kurun waktu 2 semester sehingga diperoleh hasil yang sesuai dengan kinerja yang ditunjukkan oleh guru dalam kegiatan pembelajaran.

Pengamatan kegiatan pembelajaran dapat dilakukan di kelas selama proses tatap muka tanpa harus mengganggu proses pembelajaran. Pengamatan kegiatan pembimbingan dapat dilakukan selama proses pembimbingan baik yang dilakukan dalam kelas maupun di luar kelas, baik pada saat pembimbingan individu maupun kelompok.

\section{Tahap pemberian nilai}

Pada tahap ini penilai menetapkan nilai untuk setiap kompetensi dengan skala nilai $1,2,3$, atau 4. Sebelum pemberian nilai tersebut, penilai terlebih

\footnotetext{
${ }^{10}$ Buku 2 Penilaian Kinerja Guru (PKG) Kementerian Pendidikan Nasional Direktorat Jenderal Peningkatan Mutu Pendidik dan Tenaga Kependidikan 2010.

${ }^{11}$ Buku 2 Penilaian Kinerja Guru (PKG) Kementerian Pendidikan Nasional Direktorat Jenderal Peningkatan Mutu Pendidik dan Tenaga Kependidikan 2010.
} 
dahulu memberikan skor 0,1 , atau 2 pada masing-masing indikator untuk setiap kompetensi. Pemberian skor ini harus didasarkan kepada catatan hasil pengamatan dan pemantauan serta bukti-bukti berupa dokumen lain yang dikumpulkan selama proses Penilaian Kinerja Guru.

Penilai menetapkan nilai untuk setiap indikator kinerja setiap dimensi tugas utama guru dengan skala nilai 1, 2, 3, atau 4. Sebelum pemberian nilai tersebut, penilai terlebih dahulu mengidentifikasi melalui pemantauan dan/atau pengamatan apakah setiap indikator kinerja untuk masing-masing dimensi tugas utama guru dapat teramati dan/atau terpantau, sebagai berikut: (a) Memberikan pernyataan YA (1) atau TIDAK (0) untuk setiap butir penilaian setiap indikator kinerja tugas utama dengan bantuan rubrik penilaian indikator kinerja. Penetapan YA (1) atau TIDAK (0) pada setiap butir penilaian indikator kinerja harus didasarkan kepada hasil kajian/analisis berbagai dokumen dan/atau analisa catatan pengamatan dan/atau pemantauan yang dapat menggambarkan secara utuh (tidak sebagaian) butir penilaian tersebut. (b) Berdasarkan jumlah pernyataan YA atau TIDAK tersebut, penilai menentukan nilai setiap indikator kinerja $(4,3,2$, atau 1) dengan terlebih dahulu menghitungnya. (c) Konversikan nilai tersebut dari persentase ke angka dengan mengacu kepada rentang persentase sebagai berikut:

$-75 \%<\mathrm{X} \leq 100 \%=4$

$-50 \%<\mathrm{X} \leq 75 \%=3$

$-25 \%<\mathrm{X} \leq 50 \%=2$; dan

$-0 \%<\mathrm{X} \leq 25 \%=1$.

Nilai setiap indikator kinerja untuk masing-masing tugas utama guru dijumlahkan untuk mendapatkan nilai total penilaian kinerja guru. Nilai total ini selanjutnya dikonversikan ke dalam skala nilai sesuai dengan Permennegpan dan RB No. 16 Tahun 2009. ${ }^{12}$ Distem penilaian kinerja guru, subkompetensi yang dinilai hanya 14 (empat belas) yang telah dirumuskan oleh Badan Standar Nasional Pendidikan (BSNP) dengan 78 (tujuh puluh delapan) indikator.

\section{METODE PENELITIAN}

Pendekatan penelitian adalah fenomenologis dengan jenis penelitian adalah kualitatif deskiptif yang berupaya memberikan analisis tentang masalah yang diteliti dengan tidak tebatas pada pengumpulan dan penyingkapan fakta semata. Teknik pengumpulan data melalui observasi, wawancara dan dokumentasi.

\footnotetext{
${ }^{12}$ Ratna Prilianti, "Prosedur Pelaksanaan Penilaian Kinerja Guru di Madrasah" dalam https://bdksemarang.kemenag.go.id/prosedur-pelaksanaan-penilaian-kinerja-guru-pkg-dimadrasah/
} 


\section{IMPLEMENTASI PENILAIAN KINERJA GURU DALAM SUPERVISI PEMBELAJARAN}

Usaha peningkatan profesionalitas guru dalam supervisi pembelajaran telah disesuaikan dengan informasi yang diperoleh kepala sekolah melalui pelaksanaan supervisi pembelajaran sehingga diketahui standar kompetensi yang telah dicapainya. Untuk memperoleh informasi tersebut menurut guru bahwa kepala sekolah telah melakukan penilaian kinerja guru melalui tugasnya sebagai supervisor. $^{13}$

Menurut kepala sekolah bahwa penilaian kinerja guru ini sangat diperlukan untuk mengetahui kompetensi guru dalam pembelajaran, yang selanjutnya digunakan untuk menyusun strategi dalam pengembangan profesi dari guru yang bersangkutan. Tanpa adanya supervisi tentu tidak diketahui kinerja setiap guru dalam pembelajaran. Implementasi dari penilaian kinerja guru dilakukan dalam pelaksanaan supervisi pembelajaran di kelas terhadap setiap guru. $^{14}$

Pengamatan penulis terhadap guru tampaknya antusias tatkala dilakukan supervisi pembelajaran dalam rangka memperbaiki pengelolaan pembelajaran yang dilakukannya selama ini karena diberikan masukan oleh kepala sekolah. Bahkan terlihat guru lain dan peserta didik memberikan masukan terhadap dirinya. Ketika diberikan pandangan-pandangan dari berbagai pihak terlihat tidak diabaikan begitu saja oleh guru. ${ }^{15}$

Menarik diperhatikan di sini adalah pengakuan dari peserta didik dalam mengimplementasikan penilaian kinerja guru terkadang kepala sekolah meminta pendapat dari peserta didik terhadap guru yang dinilai, karena peserta didik selain memiliki informasi terkait dengan perilaku gurunya juga terkadang peserta didik lebih jujur dalam mengemukakan pendapatnya terkait pembelajaran di kelas karena banyak hal yang diakui oleh peserta didik tidak dilihat oleh kepala sekolah. $^{16}$

Pandangan peserta didik diakui sangat bermanfaat menilai keterampilan pengelolaan kelas dari seorang guru. Hanya saja diakui pula oleh kepala sekolah bahwa penilaian dari peserta didik terkadang positif atau negatif sehingga terjadi ketakutan atau kerjasama di antara mereka untuk memberikan penilaian yang kurang baik terhadap guru yang tidak disenangi. Atas alasan ini, penilaian dari peserta didik terkadang jarang dilakukan karena sampai sekarang lebih banyak digunakan terutama untuk tujuan pengembangan guru. ${ }^{17}$

\footnotetext{
${ }^{13}$ Hamsalah Lamake, Guru PAI SDN 04 Duhiadaa, Wawancara, 15 Juli 2019

${ }^{14}$ Emi Kasim, Kepala SDN 04 Duhiadaa, Wawancara, 15 Juli 2019

${ }^{15}$ Observasi Penelitian, 15 Juli 2019.

${ }^{16}$ Abdullah Rahim, Peseta Didik SDN 04 Duhiadaa, Wawancara, 15 Juli 2019

${ }^{17}$ Emi Kasim, Kepala SDN 04 Duhiadaa, Wawancara, 15 Juli 2019
} 
Implementasi penilaian kinerja guru telah menunjukkan adanya sistem penilaian kinerja guru yang memberikan manfaat sebagai umpan balik untuk memenuhi berbagai kebutuhan di kelas, dan peluang untuk mengembangkan teknik-teknik baru dalam pembelajaran, serta mendapatkan saran dari kepala sekolah atau guru lainnya untuk membuat berbagai perubahan di dalam kelas atas berbagai problem yang dihadapinya. Kepala sekolah sebagai evaluator pembelajaran pun tampaknya memberikan pertimbangan terkait aspek keragaman keterampilan pembelajaran yang dimiliki guru. Supervisi pembelajaran yang dilakukan oleh kepala sekolah telah menggunakan berbagai sumber informasi tentang kinerja guru, sehingga memberikan penilaian secara lebih akurat. Itulah sebabnya diakui oleh kepala sekolah bahwa menilai kinerja guru di sekolah bukan sebuah hal yang sederhana. ${ }^{18}$

Hasil pengamatan di lokasi penelitian bahwa guru sudah menunjukkan kinerja maksimal di dalam menjalankan tugas khususnya dalam pembelajaran. Akan tetapi masih terlihat kurangnya rasa tanggungjawabnya menjalankan amanah, profesi yang diembannya, rasa tanggungjawab moral dipundaknya. Hal ini terlihat dari sikapnya tidak dibarengi dengan rasa tanggungjawabnya mempersiapkan segala perlengkapan sebelum melaksanakan proses pembelajaran. ${ }^{19}$

Penuturan guru bahwa bentuk tanggungjawabnya dalam mengajar yang sulit dilakukan secara konsisten adalah terkait dengan persiapan mengajar. Selama ini jika mengajar tidak dibarengi dengan rasa tanggungjawabnya mempersiapkan segala perlengkapan pembelajaran sebelum melaksanakan proses pembelajaran sehingga terkadang mengajar tidak berdasarkan kepada rancangan melainkan tiba saat tiba akal. ${ }^{20}$

Padahal menurut Diknas kinerja guru dalam pelaksanaan pembelajaran meliputi pra pembelajaran (pengecekan kesiapan kelas dan apersepsi), kegiatan inti (penguasaan materi, strategi pembelajaran, pemanfaatan media/sumber, evaluasi, penggunaan bahasa), dan menutup (refleksi, rangkuman dan tindak lanjut). Kinerja guru ditunjukkan oleh: kemampuan dalam menyusun rencana pelaksanaan pembelajaran, menerapkan strategi pembelajaran, evaluasi, menciptakan lingkungan budaya belajar, pengembangan profesi dan komunikasi. $^{21}$

\footnotetext{
${ }^{18}$ Run Arbie, Guru Senior SDN 04 Duhiadaa, Wawancara, 15 Juli 2019

${ }^{19}$ Observasi Penelitian, tanggal 22 Juli 2019

${ }^{20}$ Masra Udin Lasiki, Guru Kelas II SDN 04 Duhiadaa, Wawancara, 22 Juli 2019

${ }^{21}$ Departemen Pendidikan Nasional, Penilaian Kinerja Guru, (Jakarta: Direktorat Tenaga Kependidikan Direktorat Jendral Peningkatan Mutu Pendidik dan Tenaga Kependidikan, 2009), h.
} 10. 
Untuk lebih jelasnya terkait dengan hasil penilaian kinerja guru dapat ditunjukkan oleh data berikut ini:

Tabel: 1

Hasil Penilaian Kinerja Guru

\begin{tabular}{|l|l|l|}
\hline NO & K O M P E T E N S I & NILAI \\
\hline \hline A. Pedagogik & 4 \\
\hline 1 & Menguasai karakteristik peserta didik & 4 \\
\hline 2 & $\begin{array}{l}\text { Menguasai teori belajar dan prinsip-prinsip } \\
\text { pembelajaran yang mendidik }\end{array}$ & 4 \\
\hline 3 & Pengembangan kurikulum & 4 \\
\hline 4 & Kegiatan pembelajaran yang mendidik & 4 \\
\hline 5 & Pengembangan potensi peserta didik & 4 \\
\hline 6 & Komunikasi dengan peserta didik & 4 \\
\hline 7 & Penilaian dan evaluasi & 4 \\
\hline D. Profesional & $\begin{array}{l}\text { Penguasaan materi, struktur, konsep dan pola pikir } \\
\text { keilmuan yang mendukung mata pelajaran yang }\end{array}$ & 4 \\
\hline 14 & $\begin{array}{l}\text { Mengembangkan keprofesionalan melalui } \\
\text { tindakan yang reflektif }\end{array}$ & 32 \\
\hline Jumlah (Hasil penilaian kinerja guru) & \\
\hline
\end{tabular}

Sumber Data: Instrumen Penilaian Kinerja Guru

Pembinaan kompetensi pedagogik dan profesional guru tujuan utamanya diharapkan dapat menghasilkan pula guru yang ideal, artinya guru dapat menguasai ilmu pengetahuan yang akan diajarkan, menguasai metode dan media yang dijadikan sumber belajar, dapat mengatasi kesulitan peserta didik dalam belajar, dan dapat menjalankan administrasi sekolah. Karena pendidikan merupakan amanah kemanusiaan.

Dari data di atas diperoleh informasi bahwa penilaian kinerja guru dalam kegiatan supervisi yang dilakukan oleh kepala sekolah secara umum sudah baik dengan nilai empat. Hal ini memberikan indikasi bahwa implementasi penilaian kinerja guru telah diarahkan kepada kinerjanya dalam pelaksanaan pembelajaran yang meliputi pra pembelajaran (pengecekan kesiapan kelas dan apersepsi), kegiatan inti (penguasaan materi, strategi pembelajaran, pemanfaatan media/sumber, penilaian proses dan hasil belajar, penggunaan bahasa), dan menutup (refleksi, rangkuman dan tindak lanjut). Penilaian oleh kepala sekolah melalui kegiatan supervisi pembelajaran ini sebagai pelaksanaan dari tugasnya untuk melakukan evaluasi dan mengambil keputusan yang berhubungan dengan kinerja guru. 
Para ahli menyarankan kepala sekolah untuk mengembangkan kuesioner penilaian, yang mendorong komitmen guru dan mengurangi sikap defensif dari guru atas penilaian. Pengawas menilai kinerja guru berdasarkan kompetensi kepribadian dan kompetensi sosial dengan indikator: (1) ketaatan dalam menjalankan ajaran agama, (2) tanggungjawab, (3) kejujuran, (4) kedisiplinan, (5) keteladanan, (6) etos kerja, (7) inovasi dan kreativitas, (8) kemampuan menerima kritik dan saran, (9) kemampuan berkomunikasi, (10) kemampuan bekerjasama. ${ }^{22}$ Akan tetapi dalam pengamatan penulis bahwa terjadi perbedaan dalam implementasi penilaian kinerja guru oleh kepala sekolah melalui supervisi pembelajaran tampaknya dilakukan dengan menilai keempat kompetensi secara keseluruhan sehingga tidak dibedakan lagi antara yang dilakukan oleh kepala sekolah dengan pengawas. Penilaian kinerja guru oleh kepala sekolah tidak hanya dibatasi pada aspek kompetensi pedagogik dan profesional dalam implementasinya melainkan juga pada kompetensi kepribadian dan sosial yang menjadi tugas pengawas.

Hal ini dibenarkan oleh guru bahwa tidak ada bedanya penilaian kinerja yang dilakukan kepala sekolah maupun pengawas karena kepala sekolah dalam menilai kinerja guru berdasarkan kompetensi kepribadian dan kompetensi sosial selain kompetensi pedagogik dan sosial. Tidak dijelaskan jika penilaian kinerja guru yang dilakukan oleh kepala sekolah dan pengawas memiliki perbedaan dari aspek kompetensi yang dinilai. ${ }^{23}$

Adapun aspek lainnya yang dinilai oleh kepala sekolah setelah membaca rencana pembelajaran secara cermat dan teliti adalah aspek yang berkaitan dengan mengembangkan dan mengorganisasikan materi, media pembelajaran, dan sumber belajar, mengembangkan dan mengorganisasikan materi pembelajaran dan menentukan dan mengembangkan media pembelajaran, serta memilih sumber belajar. ${ }^{24}$ Kinerja guru dapat dilihat dan diukur berdasarkan kriteria kompetensi yang dimiliki oleh setiap guru. Berkaitan dengan kinerja guru, wujud yang perilaku yang dimaksud adalah kegiatan guru dalam pembelajaran yaitu bagaimana seorang guru merencanakan pembelajaran, melaksanakan kegiatan pembelajaran, dan menilai hasil belajar.

Sesuai dengan pedoman penyusunan portofolio sertifikasi guru dalam jabatan rencana pembelajaran meliputi aspek: (1) perumusan tujuan pembelajaran, (2) pemilihan materi ajar, (3) pengorganisasian materi ajar, (4) pemilihan sumber media pembelajaran, (4) kejelasan skenario pembelajaran, (5) kerincian skenario pembelajaran, (6) kesesuaian teknik pembelajaran dengan tujuan pembelajaran,

\footnotetext{
${ }^{22}$ Sukanti, "Peran Penilaian Kinerja Guru dalam Pengembangan Profesi Pendidik", dalam http://staffnew.uny.ac.id/upload/130799880/penelitian

${ }^{23}$ Hamsalah Lamake, Guru PAI SDN 04 Duhiadaa, Wawancara, 22 Juli 2019

${ }^{24}$ Emi Kasim, Kepala SDN 04 Duhiadaa, Wawancara, 15 Juli 2019
} 
(7) kelengkapan instrumen penilaian pembelajaran. Strategi pembelajaran yang meliputi: (1) kejelasan rumusan tujuan pembelajaran, (2) kesesuaian dengan kompetensi dasar, (3) kesesuaian materi ajar dengan tujuan pembelajaran, (4) kesesuaian tujuan dengan karakteristik peserta didik, (5) keruntutan dan sistematika materi ajar, (6) kesesuaian media/alat pembelajaran dengan tujuan pembelajaran, (7) kesesuaian media/alat pembelajaran materi pembelajaran, (8) kesesuaian dengan karakteristik peserta didik. Evaluasi meliputi (1) Kesesuaian antara teknik penilaian dengan tujuan pembelajaran (2) Kejelasan prosedur penilaian, (3) Kelengkapan instrumen penilaian(4) Mengkomunikasikan kemajuan belajar peserta didik kepada orang tua, (4) Refleksi pembelajaran (5) Evaluasi untuk mengambil keputusan dalam pembelajaran. ${ }^{25}$

Hasil wawancara dan pengamatan di atas jelaslah bahwa impelemtasi penilaian kinerja guru oleh kepala sekolah dalam kegiatan supervisi telah dilakukan dalam pembelajaran dengan tiga kegiatan yang meliputi perencanaan pembelajaran, pelaksanaan pembelajaran, dan melakukan penilaian hasil belajar. Supervisi difokuskan pada supervisi akademik dan manajerial.

Sehubungan dengan fungsinya sebagai pengajar, pendidik dan pembimbing, maka diperlukan adanya peranan pada diri seorang guru. Peranan guru ini senantiasa menggambarkan pola tingkah laku yang diharapkan dalam berbagai interaksi pembelajaran dan kegiatan lain. Namun dari berbagai kegiatan interaksi yang dilakukan, maka kegiatan pembelajaran dipandang sebagai sentral peranannya. Sebab baik disadari atau tidak bahwa sebagian dari waktu dan perhatian guru banyak dicurahkan untuk menggarap proses pembelajaran dan berinteraksi dengan peserta didiknya. ${ }^{26}$

Dalam proses pembelajaran, guru mengajarkan materi tertentu, sering menggunakan variasi gaya mengajar, dan mengajak peserta didik belajar dengan mengamati langsung dan merasakan sendiri materi pelajaran. Gaya mengajar tiap guru berbeda-beda antara satu dengan lainnya sesuai dengan pengetahuan dan pengalaman yang dimilikinya. ${ }^{27}$ Dalam pengamatan penulis, tampaknya guru memiliki kemampuan dalam menerapkan berbagai gaya dengan menunjukkan variasi suara yang kadang lemah dan keras, variasi gerakan anggota badan dengan tangan, kepala dan kaki dan variasi perpindahan posisi guru dalam kelas kadang duduk, di depan kelas atau di belakang serta samping kelas. ${ }^{28}$

Selain itu dengan gaya yang ditunjukkan oleh guru ketika mengajar menjadikan peserta didik belajar dalam suasana yang menyenangkan,

${ }^{25}$ Kemendiknas, Pedoman Penyusunan Portofolio Sertifikasi Guru dalam Jabatan, (Jakarta: Kemendiknas, 2010), h. 34.

${ }^{26}$ Sardiman A. M., Interaksi dan Motivasi Belajar-Mengajar, Pedoman Guru dan Calon Guru, Cet. VI, (Jakarta: Raja Grafindo, 1996), h. 141.

${ }^{27}$ Observasi Penelitian, tanggal 29 Juli 2019.

${ }^{28}$ Observasi Penelitian, tanggal 29 Juli 2019. 
kepercayaan diri peserta didik, semakin mudah menguasai materi belajar, dan memberikan ruang kepada peserta didik untuk menjadi mandiri dengan berbagai variasi gaya, suara dan gerakan ketika mengajar yang tidak monoton.

Penerapan gaya mengajar tampaknya dilakukan pada awal pembelajaran, kegiatan inti dan penutup yang meliputi variasi suara, variasi gerakan anggota badan dan variasi perpindahan posisi guru dalam kelas. Kendati demikian terkadang perpindahan posisi yang dilakukan guru khususnya ketika menulis di papan tulis yang membelakangi peserta didik menjadi salah satu kebiasaan guru yang kurang diperhatikan sehingga terkadang peserta didik melakukan aktivitas lainnya seperti bermain atau mengganggu temannya. ${ }^{29}$

Perilaku yang ditimbulkan oleh adanya kegiatan belajar pada peserta didik telah memberikan kemudahan bagi guru dalam melaksanakan pembelajaran terutama pencapaian tujuan. Sedangkan kegiatan belajar merupakan perubahan tingkah laku atau penampilan, dengan serangkaian kegiatan misalnya dengan membaca, mengamati, mendengarkan, meniru, dan lainsebagainya. Dengan kata lain belajar itu akan lebih baik, jika subyek belajar itu mengalami atau melakukan, jadi tidak bersifat verbalistik. Perubahan dalam belajar tampak dari hasil penilaian terkait dengan pengetahuan, keterampilan, dan sikap/perilaku peserta didik.

Dalam pengamatan penulis menunjukkan terjadi perubahan yang diakibatkan oleh adanya kinerja guru yaitu peserta didik tampak melakukan perbuatan yang ditunjukkan oleh peserta didik dalam belajar seperti kegiatan membaca, mengamati, mendengarkan, meniru yang dilakukan pada saat pembelajaran di kelas maupun di luar kelas sehingga tidak terjadi aktivitas lain di luar belajar. ${ }^{30}$

Perilaku belajar peserta didik yang penulis amati yaitu perilaku belajar positif dan perilaku belajar negatif. Perilaku belajar positif seperti terlihat pada saat pengamatan yaitu kegiatan mencatat, membaca, mengamati, mendengarkan, meniru yang dilakukan pada saat pembelajaran melalui gaya mengajar guru. Sedangkan perilaku belajar negatif tampak dari perbuatan peserta didik dalam belajar yang tidak memperhatikan, kurang mengamati, mendengarkan, tidak bisa meniru yang dilakukan oleh guru. Hanya saja perbuatan semacam ini hanya dilakukan oleh satu atau dua orang peserta didik. Perilaku belajar negatif ini adalah bagian dari kebiasaan peserta didik yang masih berusia dini dan masih suka bermain. Perilaku belajar peserta didik yang ditunjukkan dalam pembelajaran tidak lepas dari adanya gaya mengajar guru kecuali yang disebabkan oleh kebiasaan peserta didik di masa bermain misalnya kurang fokus pada penjelasan guru.

\footnotetext{
${ }^{29}$ Observasi Penelitian, tanggal 29 Juli 2019.

${ }^{30}$ Observasi Penelitian, tanggal 29 Juli 2019.
} 
Kepala sekolah sebagai supervisor melakukan upaya peningkatan kompetensi guru melalui kegiatan pengawasan terhadap penyelenggaraan proses pembelajaran tampak dari perilakunya menaruh perhatian yang utama pada peningkatan kemampuan pedagogik dan profesional gurunya, yang pada gilirannya diarahkan untuk meningkatkan mutu proses dan hasil pembelajaran.

Bahkan guru mengakui bahwa pembinaan yang tepat dan terus menerus yang diberikan kepadanya telah memberikan kemudahan dalam merencanakan, melaksanakan pembelajaran dan menilai hasil belajar. Kemudahan tersebut diperoleh melalui pembinaan langsung dari kepala sekolah yang bekerjasama dengan peserta didik dan guru lainnya untuk memperbaiki dan mengatasi masalah pembelajaran. ${ }^{31}$ Supervisi yang efektif ditunjukkan oleh adanya kinerja guru melalui upaya kepala sekolah untuk menciptakan kondisi yang layak bagi kemudahan guru dalam pembelajaran dengan kompetensi pedagogik dan profesional yang dimilikinya. Kondisi ini ditumbuhkan melalui kepemimpinan partisipatif, di mana guru merasa dihargai dan diperlukan. Dalam situasi seperti ini lahir saling kepercayaan antara kepala sekolah dengan guru, antara guru dengan guru lainnya, dan di antara pembina sendiri.

Kompetensi guru yang baik sebagai dampak adanya penerapan tugas pokok dan fungsi kepala sekolah dalam melakukan supervisi diakui pula oleh salah seorang guru bahwa merasa bebas membicarakan problemnya dalam mengajar dengan kepala sekolah karena ada keyakinan bahwa pembina selalu menghargai pikiran dan pendapatnya, melahirkan wadah kerjasama sehingga mempertemukan kebutuhan profesional guru. Melalui wadah ini, guru memiliki kesempatan untuk berpikir dan bekerja sebagai suatu kelompok dalam mengidentifikasi dan memecahkan masalah. ${ }^{32}$

Supervisi ditujukan kepada penciptaan atau pengembangan situasi pembelajaran yang lebih baik dan situasi ini tercipta oleh adanya kompetensi guru yang ditunjukkannya dalam perilaku mengajar. Hal ini dilihat dari pelaksanaan kegiatan pembelajaran yang diakibatkan oleh adanya layanan dan aktivitas kesupervisian lebih diarahkan kepada upaya memperbaiki dan meningkatkan kemampuan guru dalam mengelola kegiatan pembelajaran yang ditunjang oleh adanya kompetensi pedagogik dan profesional guru.

Atas dasar uraian di atas, maka peningkatan kompetensi supervisor dalam melaksanakan supervisi telah ditunjukkan melalui usaha pemberian bantuan kepada guru dalam bentuk layanan profesional yang diberikan oleh supervisor baik pengawas, kepala sekolah, dan pembina lainnya yang pada gilirannya telah meningkatkan mutu proses dan hasil pembelajaran yang tergambar oleh adanya kinerja guru.

\footnotetext{
${ }^{31}$ Hamsah Lamake, Guru PAI SDN 04 Duhiadaa, Wawancara, 29 Juli 2019

${ }^{32}$ Hadijah Towali, Pengawas PAI SDN 04 Duhiadaa, Wawancara, 29 Juli 2019
} 
Dengan kata lain bahwa implementasi penilaian kinerja guru dalam supervisi pembelajaran ditunjukkan oleh kepala sekolah dalam menilai pelaksanaan proses pembelajaran bagi guru mata pelajaran atau guru kelas, meliputi kegiatan merencanakan dan melaksanakan pembelajaran, mengevaluasi dan menilai, menganalisis hasil penilaian, dan melaksanakan tindak lanjut hasil penilaian dalam menerapkan 4 (empat) domain kompetensi yang harus dimiliki oleh guru sesuai dengan mata pelajaran yang diampu atau tugas tambahan yang diberikan kepadanya. Kepala sekolah lebih dalam menilai kinerja guru difokuskan pada aspek manajerial dan akademik sehingga berhubungan dengan kompetensi pedagogik dan kompetensi profesional guru sedangkan pengawas fokus pada menilai kompetensi kepribadian dan kompetensi sosial guru. Penilain kinerja guru dilakukan dengan merujuk kepada buku pedoman yang dikeluarkan oleh pemerintah.

\section{PENUTUP}

Implementasi penilaian kinerja guru dalam supervisi pembelajaran ditunjukkan oleh kepala sekolah dalam menilai pelaksanaan proses pembelajaran bagi guru mata pelajaran atau guru kelas, meliputi kegiatan merencanakan dan melaksanakan pembelajaran, mengevaluasi dan menilai, menganalisis hasil penilaian, dan melaksanakan tindak lanjut hasil penilaian dalam menerapkan 4 (empat) domain kompetensi yang harus dimiliki oleh guru sesuai dengan mata pelajaran yang diampu atau tugas tambahan sebagai guru kelas yang diberikan kepadanya. Kepala sekolah lebih dalam menilai kinerja guru difokuskan pada aspek manajerial dan akademik sehingga berhubungan dengan kompetensi pedagogik dan kompetensi profesional guru sedangkan pengawas fokus pada menilai kompetensi kepribadian dan kompetensi sosial guru. Penilain kinerja guru dilakukan dengan merujuk kepada buku pedoman yang dikeluarkan oleh pemerintah.

\section{DAFTAR PUSTAKA}

A, Elias \& Elias, Elias Modern Dictionary Arabic-English, Cairo: Elias Modern Publishing House \& Co, 1982.

Akib, Haedar, Reaktualisasi Fungsi dan Peran Kepala Sekolah Sebagai Supervisor, Jurnal Tenaga Kependidikan Vol. 3, No. 2, Universitas Negeri Makassar: Agustus 2008.

Buku 2 Penilaian Kinerja Guru (PKG) Kementerian Pendidikan Nasional Direktorat Jenderal Peningkatan Mutu Pendidik dan Tenaga Kependidikan 2010.

Daradjat, Zakiah, Ilmu Pendidikan Islam, Jakarta: Bumi Aksara, 1998.

Departemen Agama, Al-Qur'an dan Terjemahnya, Bandung: Diponegoro, 2004. 
Departemen Pendidikan Nasional RI, Undang-undang Republik Indonesia Nomor 20 Tahun 2003 Tentang Sistem Pendidikan Nasional, Bandung: Citra Umbara; 2003.

Dodot S., Implementasi Manajemen Penilaian Kinerja Guru di SMP Negeri 2 Mesuji., Tesis, Malang: Program Studi Manajemen Pendidikan, Program Pascasarjana, Universitas Negeri Lampung, 2016.

Hari Suprayogo., Implementasi Penilaian Kinerja Guru (PKG) Dalam Peningkatan Profesionalisme Guru di SDN Rampal Celaket 2 Kota Malang., Tesis, Malang: Program Studi Manajemen Pendidikan, Program Pascasarjana, Universitas Negeri Malang, 2016.

Heru Subandono, 'Kepemimpinan Kepala Sekolah dalam Membentuk Motivasi

Kerja Guru Fakultas Ilmu Sosial dan Politik Program Studi Ilmu Administrasi Kekhususan Administrasi dan Kebijakan Pendidikan”, Tesis, Jakarta: PPs UNJ, 2011.

Imron, Ali, Pembinaan Guru di Indonesia, Jakarta: Dunia Pustaka Jaya, 1995.

Kemendikbud, Pedoman Pelaksanaan Penilaian Kinerja Guru, Jakarta: Kemendikbud, 2012.

Lampiran Keputusan Direktur Jenderal Pendidikan Islam Kemenag Nomor: 7263

Tahun 2018 tentang Petunjuk Teknis Penyaluran Tunjangan Profesi Guru Bagi Guru Madrasah Tahun 2019.

Masaong, Abd. Kadim, Kepengawasan Pendidikan, Gorontalo: STIKIP Gorontalo, 2000.

Mulyasa, Uji Kompetensi dan Penilaian Kinerja Guru, Bandung: Remaja Rosdakarya, 2013.

Nurani, Yuliani, Strategi Pembelajaran; Modul 1-12, Jakarta: Universitas Terbuka, 2003.

Peraturan Menteri Negara Pendayagunaan Aparatur Negara dan Reformasi Birokrasi Nomor 16 Tahun 2009 dan Peraturan Menteri Pendidikan Nasional Nomor 16 Tahun 2007 tentang Standar Kualifikasi Akademik dan Kompetensi Guru

Peraturan Menteri Negara Pendayagunaan Aparatur Negara dan Reformasi Birokrasi Nomor 16 Tahun 2009.

Peraturan Menteri Pendidikan Nasional Republik Indonesia Nomor 16 Tahun 2007 tentang Standar Kualifikasi Akademik dan Kompetensi Guru.

Peraturan Pemerintah Nomor 19 Tahun 2005 Tentang Standar Nasional Pendidikan

Peraturan Pemerintah Nomor 55 Tahun 2007 tentang Pendidikan Agama yang dilaksanakan oleh Menteri Agama dan Permendikbud Nomor 160 Tahun 2014. 
Peraturan Pemerintah RI Nomor 32 Tahun 2013 tentang Standar Nasional Pendidikan

Peraturan Presiden Republik Indonesia No. 2/2015 Tentang Rpjmn 2015-2019 tentang Arah Kebijakan dan Strategi Pembangunan

Permennegpan dan RB No. 16 Tahun 2009 Tentang Jabatan Fungsional Guru dan Angka Kreditnya

Pidarta, Made, Pemikiran Tentang Supervisi Pendidikan, Jakarta: Bumi Aksara, 1992.

Pido, Siti Asiah, "Kinerja Guru PAI Tersertifikasi pada SMA Negeri se-Kota Gorontalo", Disertasi, Makassar: PPs UIN Alauddin Makassar, 2014.

Pupuh Fathurrohman dan M. Sobry Sutikno, Strategi Belajar Mengajar Melalui Penanaman; Konsep Umum dan Konsep Islam, Bandung: Refika Aditama, Cet. II, 2007.

Purwanto, Ngalim, Administrasi dan Supervisi Pendidikan, Bandung: Remaja Rosda Karya.

Ratna Prilianti, "Prosedur Pelaksanaan Penilaian Kinerja Guru di Madrasah" dalam https://bdksemarang.kemenag.go.id/prosedur-pelaksanaanpenilaian-kinerja-guru-pkg-di-madrasah/

Rivai, Mohamad, Administrasi dan Supervisi Pendidikan, Jakarta: Jemmers, 2000.

Sahertian, Piet, Konsep Dasar dan Teknik Supervisi Pendidikan, Jakarta: Rineka Cipta, 2000.

Sanjaya, Wina, Implementasi Kurikulum Tingkat Satuan Pendidikan Kemandirian Guru dan Kepala Sekolah, Ed. I; Cet. III; Jakarta: Bumi Aksara, 2009.

Satori, Djaman, Pokok Profesi Keguruan, Jakarta: Universitas Terbuka, 2007.

Simamora, Henry, Manajemen Sumber Daya Manusia, Yogyakarta: STIE YKPN, 2000.

Sidik, Firman. "Guru Berkualitas Untuk Sumber Daya Manusia Berkualitas." Tadbir: Jurnal Manajemen Pendidikan Islam 4.2 (2016): 109-114.

Soetopo, Hidayat, Kepemimpinan dan Supervisi Pendidikan, Jakarta: Bina Aksara, 1982.

Study, Lesson, Model Evaluasi Program (http://akhadsudrajat, wordpress.com). Diakses: 21 Juli 2019.

Suwandi, 'Pengaruh Kepemimpinan Kepala Sekolah, Budaya Kerja dan Komitmen Kerja terhadap Profesionalisme Guru di SMP Negeri Kecamatan Sumberejo Kabupaten Tanggamus”, Tesis, Lampung: Fakultas Keguruan dan Ilmu Pendidikan Magister Manajemen Pendidikan Universitas Lampung, 2016.

Tirajoh, Olga O. L., Hubungan antara Supervisi Kepala Sekolah, Budaya Kerja, dan Motivasi Berprestasi Guru, dengan Kinerja Profesional Guru pada 
SMA Negeri di Kota Manado, Disertasi, Malang: Program Studi Manajemen Pendidikan, Program Pascasarjana, Universitas Negeri Malang, 2011.

Undang-Undang Republik Indonesia No 14 Tahun 2005 Tentang Guru dan Dosen Undang-Undang Republik Indonesia No. 16 Tahun 2007 Tentang Standar Kualifikasi Akademik dan Kompetensi Guru. 